\title{
不透過型人エリーフ開口部周辺の 底面流速に関する研究 STUDY IN BOTTOM VELOCITY DISTRIBUTION AROUND OPENING OF IMPERMEABLE ARTIFICAL REEFS
}

\author{
南將人 $1 \cdot$ 真野明 2 \\ Masato MINAMI, Akira MANO \\ 1正会員 工修 八戸高専 建設環境工学科（广039-1192 八戸市田面木上野平16-1） \\ 2正会員 工博 東北大学大学院 災害制御研究センター
}

\begin{abstract}
Artificial reefs have been constructed for protecting coast from erosion and for replacing detached breakwaters. The construction causes topographical change around them. Bottom flow and water surface variation and others caused topographical change. So the experiment using 3-ADV (Acoustic Doppler Velocity Meter) to measure the bottom velocity profile around opening was carried out. And the topographical change by movable bed was investigated.

This study shows the result of the distribution of bottom velocity around opening. The result shows that the mean velocity of flow at offshore side of reef was different from that at shore side reef. The former region has cyclic current field. And the change of topographical flux was nearly equals to the calculation results that using the Brown's theory and incident wave conditions.
\end{abstract}

Key Words: artificial reefs, bottom current, $A D V$, topography change

\section{1. はじめに}

潜堤や人エリーフを使用した場合，設置後に地形 変化を生じる事が知られている. 施工前後に実施し た深浅測量図を用いた解析結果によると ${ }^{1), 2)}$ ，これ らを 2 基使用して開口部を有した場合には，開口部 中央あるいは沖側に侵食域が発生した事例が確認さ れている. 人エリーフや潜堤などの海岸保全施設設 置後, 汀線周辺では堆積となりその効果が見られる もの，構造物周辺では局所的な侵食が発生し，構造 物の沈下などが起り施設維持のメンテナンスが必要 となる場合がある。この要因として，陸側に伝播し た波が「戻り流れ」となって開口部から沖側に流れ 出る時の強い流れによって地形変化を生じているこ とが考えられる. 潜堤背後の平均流速変化に関する 研究には, 喜岡ら ${ }^{3)}$ の不規則波を用いた実験や宇多 ら4)などがあるが，開口部中央に関する研究例は数 少ない。

本研究は, 開口部周辺の底面付近の戻り流れを 3 次元ADV (Acoustic Doppler Velocimeter)によって 測定し, 底面付近における平均流速成分の平面流速 分布と入射波諸元からの概算方法について検討した ものである.

\section{2. 実験方法}

\section{（1）実験水槽と模型配置}

開口部周辺の底面流速を室内水槽によって測定し た. 実験に用いた水槽は，長さ $9.0 \mathrm{~m}$ ，幅 $0.8 \mathrm{~m}$ ，最大 水深 $0.8 \mathrm{~m}$ であり, 水路の一部は両面アクリル製と なっており, 水路側面から水位変動等の観測が可能 である.この水路の一方には，プランジャー型規則 波造波装置が取りつけられている。この造波機直前 には，波進行方向に対して直角方向 $5.0 \mathrm{~cm}$ 間隔で消 波用ネットを設置して横波の発生を防いだ。また反 対側の水路の端部には, $1: 2$ の斜面に消波ブロック を設置して消波した。人エリーフ模型は，造波板か ら $3.0 \mathrm{~m}$ 離した地点に既往の研究事例 ${ }^{5}$ を参考に幅 $37 \mathrm{~cm}$, 堤長 $64 \mathrm{~cm}$, 高さ $17.5 \mathrm{~cm}$, 法面勾配 $1: 2$ の不透 過性型（ベニヤ板）の模型を設置した。リーフ堤長 は, 長さ $40 \mathrm{~cm}$ と $24 \mathrm{~cm} に$ 分割し, リーフ長さ $(\mathrm{Lr})$ と 開口部幅 (W) との比は, 海浜安定の目安となる諸 元である $\mathrm{Lr} / \mathrm{W}=4$ となるようにした ${ }^{6), 7)}$. また，水路 床には，高さ $50 \mathrm{~mm}$ で砂（ $\left.\mathrm{d}_{50}=0.65 \mathrm{~mm}, \mathrm{~s}=2.8\right)$ を敷 き詰め, 流速および水位変動に加え, 砂の移動状況 を目視観測および砂面計による地形測定を行った。 図一 1 に水槽諸元と模型位置を示す。 


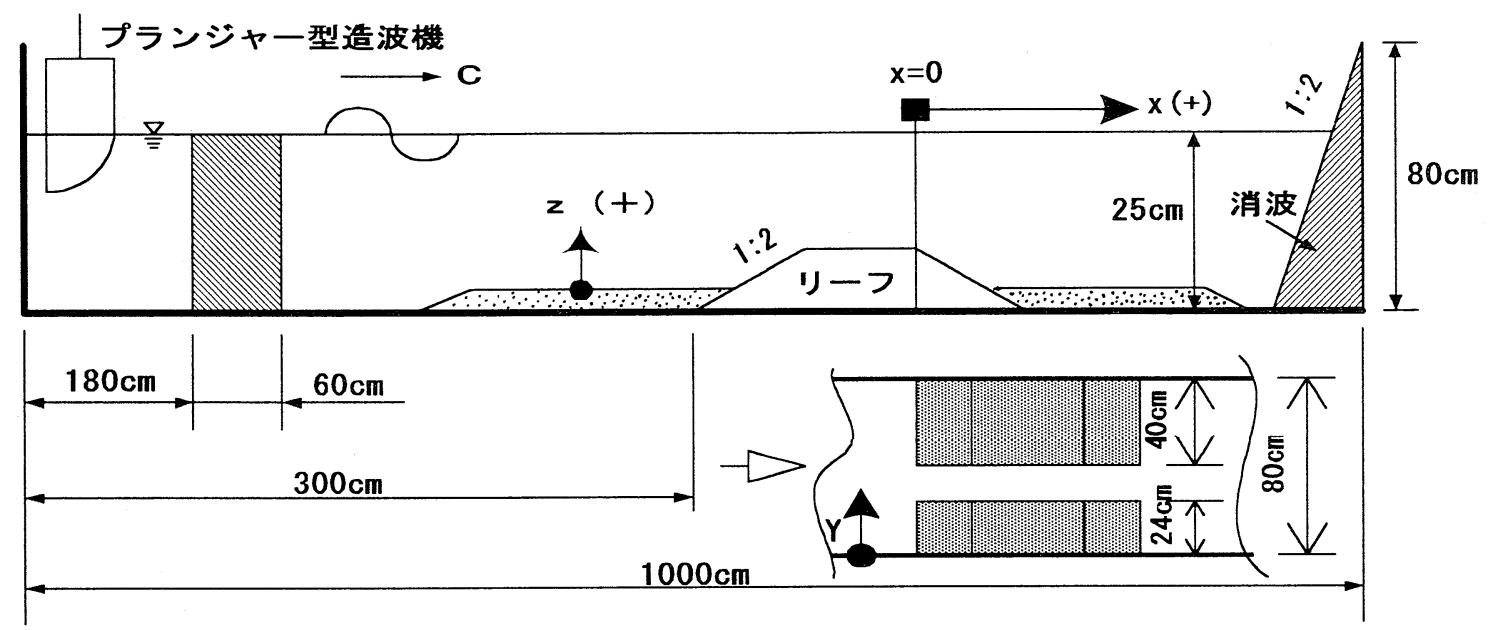

図-1 水槽緒元と模型配置図

\section{（2）実験波諸元}

実験条件は，底面に敷き詰めた砂の移動状況を目 視観測して試行錯誤を繰り返し，底質移動を生じた 時の波浪諸元とした。実験条件を表-1に示す。

表-1 実験条件

\begin{tabular}{|c|c|}
\hline 入射波高 (H) $8.8 \mathrm{~cm}$ & 周期 (T) 0.9 秒 \\
\hline リーフ設置水深 (D) $20 \mathrm{~cm}$ & 波形勾配 (H/L) 0.08 \\
\hline
\end{tabular}

\section{（3）測定装置および測定方法}

測定項目は，リーフ周辺の水位変動，底面付近の 流速変動そして地形変化の 3 項目とした。

水位変動は容量式波高計（東京計測(㑣）を 2 台, また地形変化測定には接触式砂面計（東京計測(㑣) を 1 台用いた。底面の流速には，3 次元超音波ドッ プラー流速計 (3-Dimentional Acoustic Doppler Velocimeter：Sontek社)を 2 台用いた. 写真-1に示 すように,このセンサーは, トランスミッタ (A) から発信した超音波を $50 \mathrm{~mm}$ 下部における $3 \mathrm{~mm}$ 立方部 $\left(0.25 \mathrm{~cm}^{3}\right)$ からの反射を枝状に張り出したレシーバ (写真中B, C, D) で受信する事で， 3 次元的に最高 $25 \mathrm{~Hz}$ で測定するものである．流速測定は，水路脇に 取り付けられている台車に $14 \mathrm{~cm}$ 離して 2 台を取りつ け，波進行方向に $4 \mathrm{~cm}$ ピッチで移動し，約 10 波間の 流速を測定し，パソコンに流速データを記録しなが ら全1200点程計測した。なお，計測中，造波は連続 して行い, 計測範囲はX=-200〜 $170 \mathrm{~cm}$ とした.

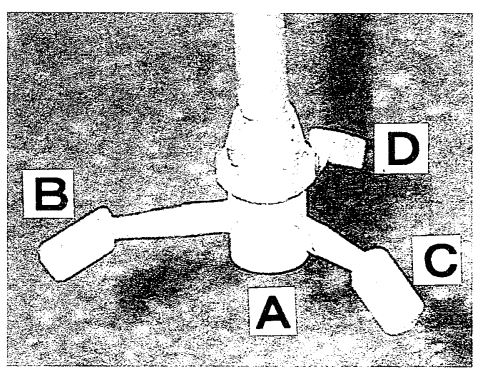

写真ー1 3-ADVセンサー部

\section{3. 実験結果および考察}

\section{（1）流速の時系列変化例}

流速の測定位置高さ (Z) は砂面上4～8 $8 \mathrm{~mm}$ とした。 目視観測の結果, リーフ上の波峰はほぼリーフに平 行であり回折他の影響は小さいものと考えられる.

波進行方向流速の経時変化のリーフ岸側と沖側と の比較結果を図-2に示す。また, 沖側 $(X=-110 \mathrm{~cm})$, リーフ中央部 $(X=-18 \mathrm{~cm})$ そして岸側 $(X=70 \mathrm{~cm})$ 位置で の流速 3 成分の測定例を図-3 5に示す.

図-2中の○印はリーフ沖側での流速を，ロ印は リーフ岸側での水平流速結果を示す. リーフ岸側で の流速変動を見ると，上下対称な変化となっており， また水平流速の最大值および最小值の絶対値はほぼ 等しくなっている。また，約10波間の時間平均流速 （約250個の平均）はほぼ 0 であった。一方，沖側 （=造波機側）における水平流速は，計測中の流速 はすべて沖側方向となっており, 時間平均流速は一 $15 \mathrm{~cm} / \mathrm{s}$ と沖側（=造波機方向）にシフトしていた. また，平均值からのずれの最大值と最小值はほぼ同 程度であり，波の進行方向とは逆向きの流速で振動 を生じていた。

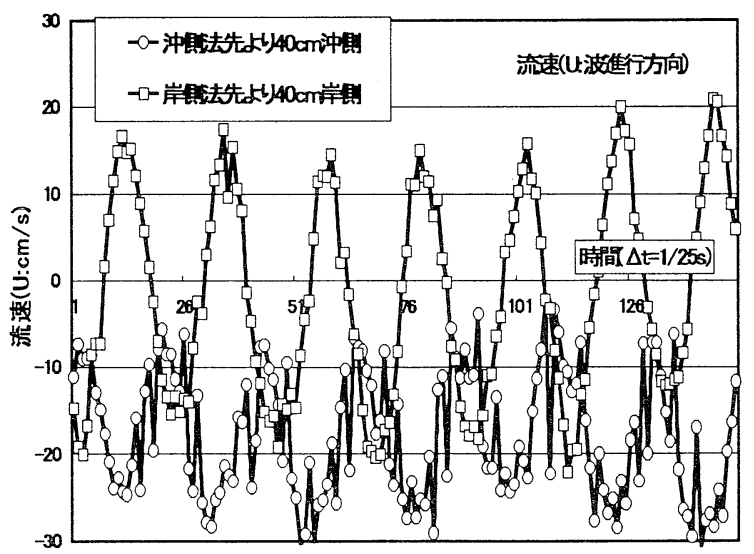

図-2 流速の時系列変化測定例 
（2）リーフ沖侧, 中央, 岸侧での流速経時変化

図-3にリーフ沖側での流速結果を示す.

波進行方向成分 (U) は, 岸向きの最大流速 $5.0 \mathrm{~cm} / \mathrm{s}$, 沖向きの最大流速 $18.0 \mathrm{~cm} / \mathrm{s}$, 平均の振幅 は $10.5 \mathrm{~cm} / \mathrm{s}$ の振動成分を有している. 平均流速は $10.5 \mathrm{~cm} / \mathrm{s}$ となり沖向きの流れとなっていた. 波進行 方向直角方向の流速成分 $(V)$ は $-2.0 \mathrm{~cm} / \mathrm{s}$ から $18.0 \mathrm{~cm} / \mathrm{s}$ の範囲となり, 平均流 $5.0 \mathrm{~cm} / \mathrm{s}$ となってお り，上下対象の振動成分となっている.これらに対 し, 鉛直方向成分 $(W)$ については, $-2.0 \mathrm{~cm} / \mathrm{s} \sim$ $2.0 \mathrm{~cm} / \mathrm{s}$ となっており他の 2 成分に比べて振幅成分 は小さくなっている，微小振幅波理論を用いた底面 流速の振幅は $16.0 \mathrm{~cm} / \mathrm{s}$ となり微小振幅波とほぼ同じ 值となっていた．同様に鉛直流速成分の振幅につい ては, 微小振幅波理論による $0.6 \mathrm{~cm} / \mathrm{s}$ の約 3 倍と なっていた.

次にリーフの開口部中央での流速の経時変化結 果を図-4に示す．波の進行方向成分（U）の変化を 見ると, 沖向きの流速の絶対值は増加し, 沖向流れ 成分が大きくなっている，また，流速值がすべて負 となっている事から開口部での底面流速は沖向きの 流れとなっている. 波進行方向直角成分（V) につ いては平均流速 $5.0 \mathrm{~cm} / \mathrm{s}$ となっており, リーフの長 さ $40 \mathrm{~cm}$ 側にやや傾いている．鉛直方向成分（W）に ついては，振動成分の振幅は $3.0 \mathrm{~cm} / \mathrm{s}$ となっていた。 波進行成分との位相を比較すると，流速Uに比べて 長周期成分が卓越している. 前述の微小振幅波理論 を用いた流速成分との比較は，Uの場合は，0.7倍， W成分は3.0倍となっていた．鉛直方向の流速振幅に ついては，沖側に比べて大きくなっており，リーフ 上での強制砕波および戻り流れの影響によって微小 振幅波理論の適用性が低くなっているものと考えら れる. 岩垣による定形進行波解の適用領域 と実験波諸元は微小振幅波理論適用範囲内となり， 底面の波進行方向の振幅についてはほぼこの理論で 求められる.

次に岸側での流速の経時変化を図-5に示す.

波進行方向成分（U）は岸向沖向の流速の絶対值は ほぼ同じく $15 \mathrm{~cm} / \mathrm{s}$, 時間平均流速はほぼ 0 であり, 前述の沖側と開口部中央での平均流速の特性とは大 きく異なっていた。 また，波進行方向直角成分

(V) と鉛直方向成分 (W) とはほぼ同じ変動, 振幅 特性を有しており, 流速 $(\mathrm{V})$ の振幅は $4.0 \mathrm{~cm} / \mathrm{s}$ となり, 波進行方向成分（U）とほぼ同様の移位相を有した 流速変化となっている. 鉛直方向成分の振幅は $2.0 \mathrm{~cm} / \mathrm{s}$ となっており, 水平成分の $1 / 7$ となっている. 入射波諸元を用いた場合の微小振幅波理論の底面に おける水平および鉛直成分の比は，それぞれ 1.2 倍, 5. 0倍となっており水平流速については概算できる.

特に, 波進行方向の平均流速についてはリーフ沖 側と開口部そして陸側での特性が異なっており,こ れらの大きさや速度勾配によって砂移動が大きく異 なるものと考えられ, 構造物設置に伴う地形変化の 予測のためにこれらの諸元が重要である.

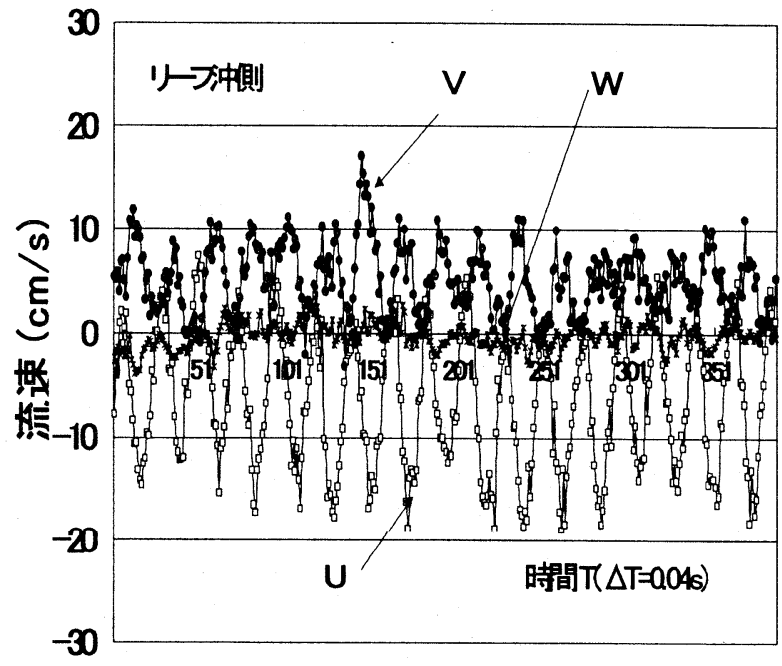

図-3 流速の経時変化（沖側 $\mathrm{X}=-110 \mathrm{~cm} ）$

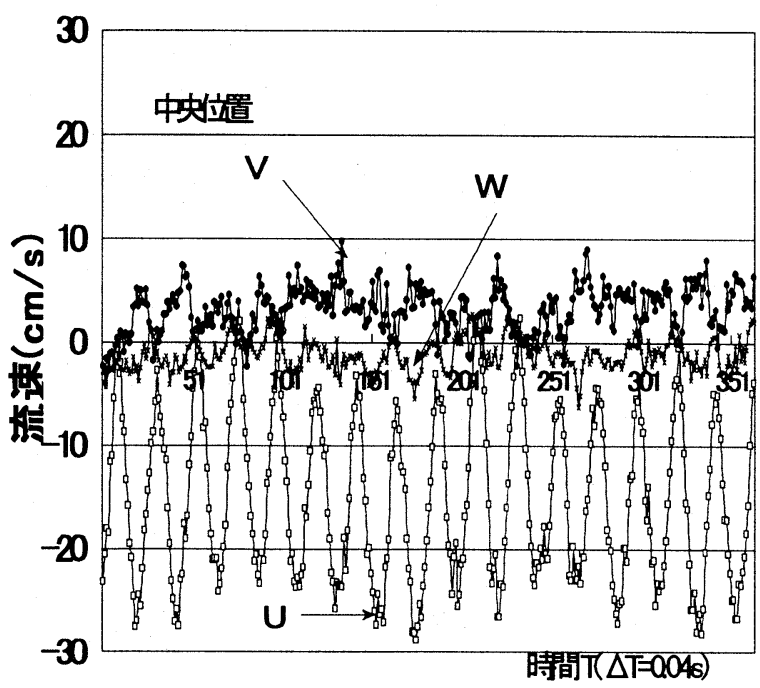

図-4 流速の経時変化（開口部 : X=-18cm）

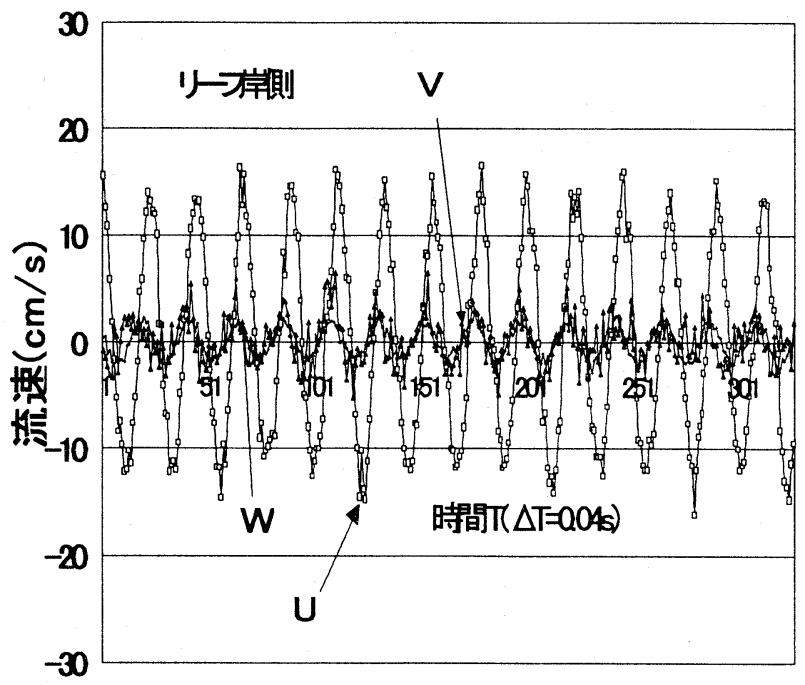

図- 5 流速の経時変化（岸側 $: X=70 \mathrm{~cm} ）$ 


\section{（3）入射波諸元を用いた戻り流れ速度の概算}

開口部中央で測定された戻り流れ速度の大きさと 微小振幅波理論を用いた余剩質量フラックスとを比 較し，開口部から戻り流れ速度の算出法について検 討した.

微小振幅波理論を用いると，単位幅当たりの質量 輸送速度は次式で求められる.

$$
u=\frac{E}{C}
$$

ここで，E:波のエネルギー密度 $\mathrm{C}:$ 長波の波速

を表す。

人エリーフおよび開口部から岸側に透過した波が リーフ天端上で砕波して岸側に流入し，その余剩質 量フラックスが，開口部から沖側に戻り流れに向か うとして，リーフ堤長 ( $\mathrm{Lr}$ ) および開口部幅 (W) そして水深 (h) を用い, 戻り流れが底面から水面ま で一様と仮定して，入射波諸元を用いた断面平均流 速の算定式は次式で表される.

$$
u_{c}=\frac{1}{8} \frac{g H^{2}}{\sqrt{g h^{3}}} \frac{W+L_{r}}{W}
$$

開口部中央における岸沖方向流速成分 (U) の分布 図を図一に示す。この範囲の水平流速は，他の領域 より沖向流速が速くなり, 特に沖側肩部での流速が 最も速くなっていた. また, 速度勾配を求めると沖 側と岸側で異なり，砂の連続式を考慮するとこの変 曲点（図中のA点）で地形変化が生じるものと考え られる。
入射波諸元を用いてこの開口部中央およびリーフ天 端から岸側に流入した余剩質量が開口部からの単位 幅当たりの戻り流れ速度との比較結果は以下に示す 通りである．開口部中央部（図中B）での流速との 比は, $1.1 \sim 1.6$ 倍となっており, 鉛直方向に一様分 布と仮定はしているものの，比較的簡単な式で開口 部からの流出速度を概算できる事が分かった。

\section{（4）底面流速ベクトル図}

測定した底面流速（砂面上 $4 \sim 8 \mathrm{~mm}$ ） の水平平均流 速成分 $(\mathrm{U}, \mathrm{V})$ のベクトル図を図-7に示す.

リーフ岸側ではほぼ０であるのに対し，開口部岸 側から沖側にかけて，波進行方向と異なる流れが発 達している。.また，リーフ沖側法先付近には開口部 に向うように循環流が発達し, 開口部からの戻り流 れが水中噴流状態となって沖側に流れ出し，それに 引き込まれる様なべクトル分布となっている.

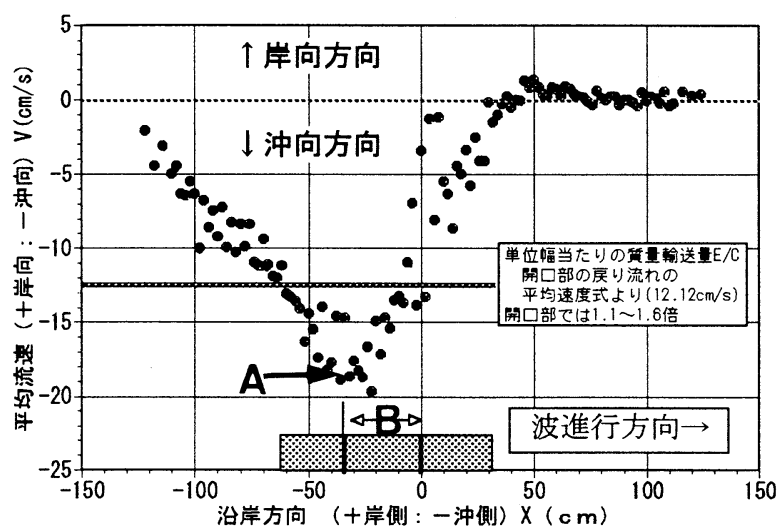

図一 6 余剩質量による断面平均流速との比較

波進行方向 $\rightarrow$

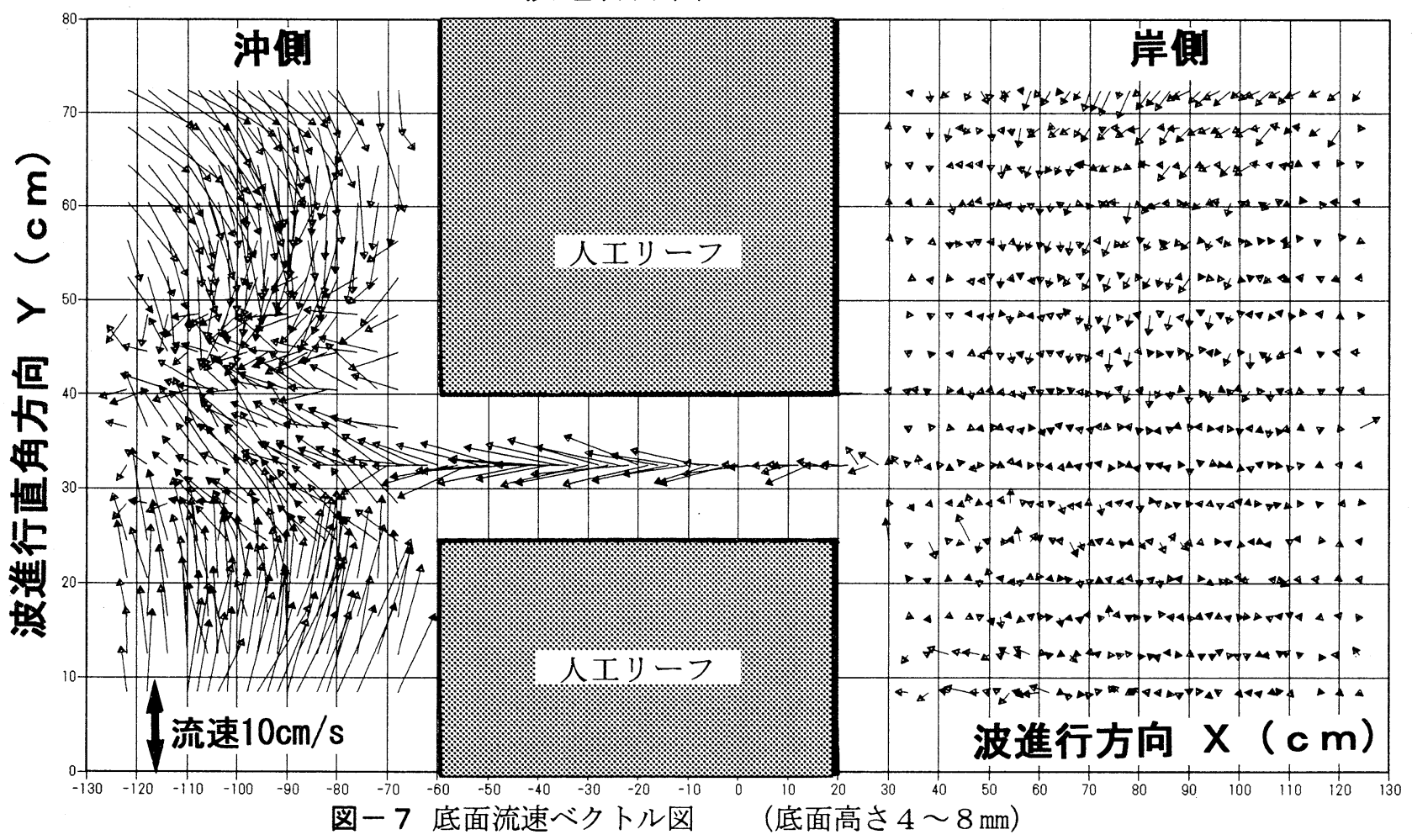




\section{4. 地形変化量分布と流速ベクトル図}

\section{（1）開口中央の地形変化量分布}

人エリーフ周辺の地形変化と流速分布との関連を 検討することを目的として移動床実験を実施した. また，人エリーフ開口部周辺の漂砂量の概算方法に ついて検討した.

人エリ・フ開口部中心線に沿って $8 \mathrm{~cm}$ 間隔で測定し た岸沖方向の地形変化量（造波60分間）を図-8に示 す。岸側法先位置で $2 \mathrm{~mm}$ 程度侵食し, 沖側肩部付近 に軽石 $\left(\mathrm{d}_{50}=2.0 \mathrm{~mm}\right.$, 比重 2.0$)$ が最大高さ $6 \mathrm{~mm}$ で堆積 していたが，それ以外の領域ではほとんど地形変化 は見られなかった。また，岸沖方向の堆積形状を見 ると, 沖側に比べて岸側での傾斜勾配が緩くなって おり,また目視観測の結果, 堆積した砂は岸側から 沖側に向って移動していた.また，この堆積領域は, ピラミッド形状をしていた.さらに目視観測の結果, 岸側肩部に集まり始めた塊が造波時間の経過と共に 沖側に移動し, 沖側肩部付近で往復運動を繰り返し ていた.

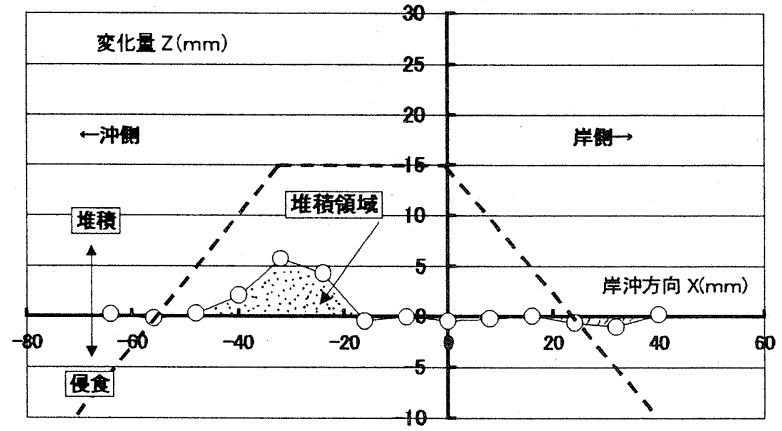

図一8 地形変化量分布図

\section{(2 漂砂量の概算方法}

開口部法肩付近に堆積した砂を対称に漂砂量の概 算を行った。開口部中央には戻り流れが卓越する事 より, Brownの掃流砂・を用いた。

$$
q_{B}=\frac{10 \cdot \tau_{*}}{s^{2} \cdot g^{2} \cdot d}
$$

ここに, $\mathrm{q}_{\mathrm{B}}$ : 単位幅当たりの漂砂量フラックス, $\tau_{*}:$ 掃流力, $\mathrm{g}:$ 重力加速度, $\mathrm{s}$ : 砂の比重, $\mathrm{d}$ : 砂の粒径,

を示す。

上記は，単位幅当たり単位時間当たりの漂砂量つ ラックスを表しており, 河床変動などを解析する際 によく使用されている。この式に造波時間（T）と開 口部幅（W）を乗じ開口部を通過する砂の全掃流砂 量 $\left(\mathrm{V}_{\mathrm{B}}\right)$ とすると，その算定式は次式で表される。

$$
V_{B}=\int W \cdot q_{B} \cdot d t=\frac{10}{s^{2} \cdot g^{2} \cdot d} C_{f}^{2.5} \cdot W \cdot u_{R}^{5} \cdot \Delta t
$$

ここに, $\mathrm{C}_{\mathrm{f}}$ :摩擦抵抗係数, $\mathrm{W}$ : 開口部幅

$\mathrm{u}_{\mathrm{R}}$ : 戻り流れ速度, $\Delta \mathrm{t}$ : 波の作用時間 を示す.また, $\mathrm{C}_{\mathrm{f}}$ は

$$
C_{f}=\frac{g}{C^{2}}=\frac{n^{2}}{R^{1 / 3}}
$$

ここに, C:Chezy係数, $\mathrm{n}$ :Manningの粗度係数 $\mathrm{R}$ : 径深

を示す。

開口部に堆積したピラミッド状に堆積した砂の体 積（堆積形状を三角錐と仮定した）を䣓とし，前述 の実験結果を用いて算出した量は， $V_{\mathrm{E}}$ は $47 \mathrm{~cm}^{3}$ であっ た. 式 (4)で算出した值を比較してみると $V_{\mathrm{E}} / V_{\mathrm{B}}=1.6$ となることから，入射波諸元を用いた開口部からの 戻り流れ速度と開口部幅と高さを用いる事で, 漂砂 量の概算が可能である。

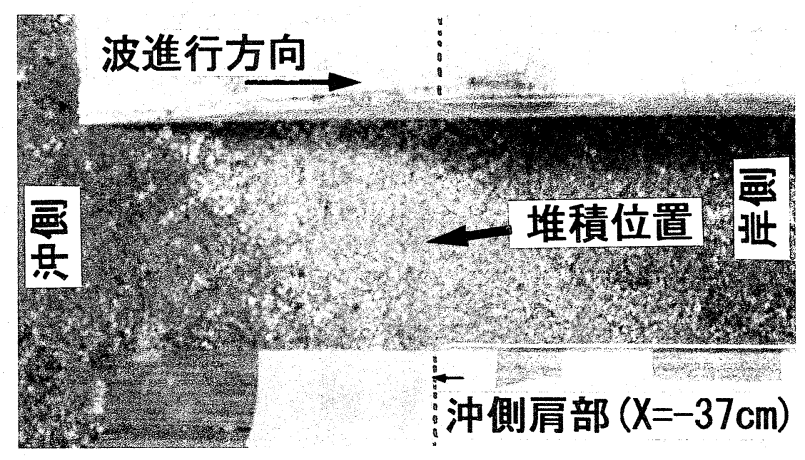

写真 -2 砂の堆積状況

\section{5. 結論}

本研究によって得られた結論を以下に列記する.

1） $3 \mathrm{D}-\mathrm{ADV}$ 用いて人エリーフ開口部周辺の底面流 速分布（高さ $4 \sim 8 \mathrm{~mm}$ 範囲）を測定し，流速分布特 性と入射波諸元および構造物諸元を用いた開口部 中央での戻り流れ速度概算方法について検討した。

2) 時間平均流速ベクトルは, リーフの沖側と岸側で 異なっており，岸側ではほぼ流速が 0 であるのに 対し, 沖側では開口部からの水中噴流状の噴き出 しにより，開口部中心に向う循環流が生じていた。

3) 開口部中.央における実験值と余剩質量フラックス と構造物諸元を用いた断面平均流速とはほぼ等し く, 比較的簡単な式が求められた。

4) 移動床実験で開口部沖側肩部に発生した堆積域の 漂砂量フラックスは, Brownの掃流砂公式によっ て求められた。 


\section{参考文献}

1) 南將人, 真野明 : 人エリーフ・潜堤の施工事例調査, 海洋開発論文集, Vol.17, pp.229-234，2001.

2) 南將人, 真野明 : 潜堤開口部周辺の地形変化に関する 研究, 海岸工学論文集第48巻, pp. 951-955, 2001.

3) 喜岡涉, 松野忠幸, 岡本正由, 佐藤公己 : 潜堤背後の 平均水位と長周期変動に関する実験的研究, 海岸工学 論文集，第38巻, pp.306-310, 1991.

4) 宇多高明，小俣篤：人工リーフの設計法，土木技術資 料，第29巻，第12号, pp.26-31.1987.
5) 海岸波動【波・構造物・地盤の相互作用の解析法】，土木 学会海岸工学委員会研究現況レビュ一小委員会編,1994.

6) 海岸保全施設築造基準解説, 海岸保全施設築造基準連 絡協議会編, 2002

7) 海岸保全施設設計便覧2000年度版，土木学会，2000.12.

8) 岩垣雄一 : 最新海岸工学, 森北出版, p. 54, 1987.

9) Brown, C. B.: Engineering Hydraulics, edited by H. Rouse, John Wiley \& Sons, Inc., New York, N. Y., 1950. 